\title{
Muhammad Abi Zahra’s Method in The Variety of Qira`āt in Tafsīr Zahrah al-Tafāsīr
}

\author{
منهج محمد أبي زهرة في القراءات من خلال تفسيره زهرة التفاسير \\ Moh. Abdul Kholiq Hasan \\ Universitas Islam Negeri Raden Mas Said Surakarta \\ Email: hasanuniversitas@gmail.com
}

Article Accepted: November 18, 2021, Revised: December 28, 2021, Approved: 06 January, 2022

\begin{abstract}
الملخص
كان الإمام محممد أبوزهرة من أحد المفسرين المعاصيرين الذي له اهتمام واضح بوجوه القراءات واستفادها

لتفسير القرآن. و تهدف هذه الدراسـة إلى معرفة منهج محمد أبي زهرة في معالجة مسائل القراءات في

تفسيره. مستخدمة منهج البحث الوصفي التحليلي من خلال تتبع واستقراء القراءات الواردة في تفسيره

زهرة التفاسير. وقد توصلت الدراسة إلى النتائج التي تدل على أن للإمام محمد أبي زهرة مناهج خاصية في

معالجة القراءات. وهي كالأتي (1) عند عرضه للقراءات أنه في الغالب لا ينسب القراءات إلى صياحبها إلا

بالنسبة الضئيلة (2) الحرص على عرض وتعيين القراءات المتواترة (3) الجمع بين القراءات (4) بيان

القراءات وتوجيهها (5) وتوجيه القراءات الشـاذة. وكان من بين أهدافه إلى الاهتمام بالقراءات في تفسيره

أولا: تأكيده أن القراءات المتو اترة كلها من القرآن، و أن المعانى تلك القراءات كلها مقصهود في القرآن دليل

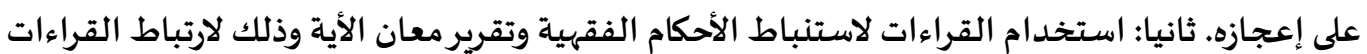

الوثيق بموضع تفسيرواختلاف الأحكام.

الكلمات المفتاحية: محمدل أبي زهرق، زهرة التفاسير، المنهج، القراءات.

Abstract

This research aims at investigating Abi Zahra's method towards the variety of the Qira'ât. This research paper employs the analytic descriptive method by exploring and analyzing the variety of Qira àt in the Zahrah al-Tafāsī. The results showed that Abi Zahra's interaction methods towards the variety of Qira āt are: (1) When presenting the Qiraāt, he often does not attribute the Qira'ât to their owner except in a small proportion (2) the diligence to present the Qira 'àt Mutawātirah (3) Combine the Qira'ât (4) clarifying and explaining the Qira'āt (5) and explaining the Qira'āt Syāżah. Among his goals was to pay attention to the recitations in his interpretation, first: his assertion that all the frequent the Qira 'àt are from the Qur'an, and that the meanings of those Qira'āt are all intended in the Qur'an and evidence of its miracles. Second: Using the Qira'ât to derive jurisprudential rulings and determine the meaning of the verse, because the Qira'ât are closely related to the position of of interpretation and the difference in rulings.
\end{abstract}

Keywords: Muhammad Abi Zahra, Zahrah al-Tafāsīr, Method, Qirā̄t 
إن القراءات من المسائل القر آنية المهمة. حيث لا يكاد من المفسرين إلاويهتمون بها في تفاسيرهم، وهي من

المصادر المهمة في التفسير، لأن لها أثرا واضحا في تفسير القرآن الكريم. فكثيرا ما يترتب على اختلافها الاختلاف في

الفهه والأحكام.3 وقد يتضح مراد الأية من خلال القراءة الأخرى الواردة في تلك الأية. و ذلك لأن وجوه القراءات تكثر

من احتمال المعاني في الآية الواحدة. و المفسر لا بد له من الدراية التامة بوجوه القراءات والاستفادة منها عند تفسير القرآن.5

هذا، و إن الناظر في تفسير" زهرة التفاسير" يجد أن الإمام محمد أبا زهرة - رحمه الله - أورد وجوه

القراءات كثيرا واهتم بها في سياق تفسيره. ذلك بسبب ارتباط القراءات الوثيق بموضع التفسيرواختلاف الأحكام.6

وقد قال في هذا الصدد عند مقدمة تفسيره، " أننا لَانذكرمن القراءات المختلفة إلا إذا ترتب على اختلافها الاختلاف

في المعاني، فنذكرها كلها، على أنها كلها قرآن، وأن هذه المعاني كلها مقصيود في القرآن السامي، ودليل على إعجازه".7

هذا، وقد كثرت الدراسـات حول الإمام محمد أبي زهرة وتفسيره قبل هذه الدراسة. ومن بينها الدراسة التي

قام بها محمد بدرون (Muhammad Badrun) إذ تحدث في دراسته عن أبي زهرة وتفسيره بشكل عام دون التعرض إلى تفاصيله. ${ }^{8}$ محمد أبي زهرة.وهناك دراسات أخري ولكن أكثرها تتعلق بأراء الإمام محمد أبي زهرة الفقهية .10 أو معالم فكرته

${ }^{1}$ Muhammad Irham, "IMPLIKASI PERBEDAAN QIRAAT TERHADAP PENAFSIRAN ALQURAN," AlBayan: Jurnal Studi Ilmu Al- Qur'an Dan Tafsir 5, no. 1 (July 13, 2020): 55-61, https://doi.org/10.15575/albayan.v5i1.8563.

${ }^{2}$ Moh. Abdul Kholiq Hasan, "The Tafsīr Bi Al-Ma'sūur and Bi Al-Ra'yī in The Commentary of Abū Ja'far AlȚahāāī (Study in Aḥkām Al-Qur'ān Al-Karīm,’ Jurnal Studi Al-Qur'an 17, no. 2 (2021): 179-206.

3 Muhammad Misbah, "PEMBACAAN AL-QUR ' AN DALAM PERSPEKTIF IMĀM AL-QURṬUB," Hermeunetik 8, no. 1 (2014): 89-112, https://doi.org/10.21043/hermeneutik.v8i1.907.

${ }^{4}$ Khālid 'Abd al-Rahmān Al-'Ak, Usūulu Al-Tafsìr Wa Qawā'Iduh (Bairut: Dār al-Nafãis, 1986), 349.

${ }^{5}$ Moh. Abdul Kholiq Hasan, "AL- ȚAHĀW̄'S'S METHOD TOWARDS THE VARIETY OF QIRAĀT IN TAFSIR AHYKĀM AL-QUR'ĀN AND ITS IMPLICATION TO ISTINBĀṬ AL-AḤKĀM," Jurnal Studi Ilmu-Ilmu Al-Qur'an Dan Hadis 22, no. 1 (January 30, 2021): 93, https://doi.org/10.14421/qh.2021.2201-05.

${ }^{6}$ Halimah B, "PERBEDAAN QIRA'AT DAN PENGARUHNYA DALAM ISTINBATH HUKUM," AlRisalah 19, no. 1 Mei (2019): 97-98.

${ }^{7}$ Muhammad Abū Zahrah, Zahrah Al-Tafāsīr (Kairo: Dār al-Fikr al-'Arabi, n.d.), 1/19.

${ }^{8}$ Muhammad Badrun, "Mengenal Muhammad Abu Zahrah Sebagai Mufassir," At-Ta'dib: Journal of Pesantren Education 6, no. 1 (2011): 79-94, https://doi.org/http://dx.doi.org/10.21111/at-tadib.v6i1.548.

9 Syahrullah Syahrullah, "Nuansa Fiqhiyah Dalam Zahrah Al-Tafasir Karya Muhammad Abu Zahrah," AlBayan: Jurnal Studi Ilmu Al- Qur'an Dan Tafsir 1, no. 2 (2016): 131-38, https://doi.org/10.15575/albayan.v1i2.1597. 
وهذه الدراسة تحاول معرفة منهج الإمام محمد أبي زهرة في معالجة مسائل القراءات وإبرازسمات تفسيره من حيث اختلافات القراءات في تفسيره المعنون " زهرة التفاسير". وذلك لأن الإمام محمد أبا زهرة كان من المفسرين المعاصرين البارزين الذين لهم اهتمام واضح بوجوه القراءات في تفسيره. 12 وقد عقد فضيلته مبحثا خاصا في كتابه الجليل "المعجزة الكبري: القرآن" عن قراءات القرآن. وهذا إن دل على شيء إنما يدل على تعمقه في علم القراءات.13 ومن هنا تأتي أهمية الدراسـة علميا، ألا وهي ملامح منهج الإمام محمد أبي زهرة في التفسير من خلال الاستغلال بالقراءات.

منهجية البحث

استعمل الباحث في هذه الدراسة منهج البحث الوصفي التحليلي بطريقة تحليل المحتوي أو ما يسهى بـ

(content analysis) البيانات الثانوية من كل المعلومات التي لها صلة بموضوع الدراسة سواء كان من المراجع المكتبية و المجلات المحكمة. ثم عرض تلك البيانات الأسـاسية و الثانوية و إجراء دراسة وصفية تحليلية بالاستنباط والاستنتاج.

$$
\text { نبذة عن سيرة الإمام محمد أبي زهرة }
$$

هو محمد بن أحمد بن مصطفى أبو زهرة، المولود في مارس عام 1316هـ أو 1898م بالمحلة الكبرى، إحدى

مدن المحافظة الغربية بمصر. وأسرته معروفة في هذا البلد يطلق عليها اسم أبو زهرة. قد نشأ في بيت علم ودين وفضيلة، فحفظ القرآن الكريم ولم يتجاوز التاسعة من عمره في الكُتّاب الموجود في قريته. وكان والده مشهورا بالصلاح والالتزام بالدين الحنيف ومكارم الأخلاق. وكانت والدته حافظة للقرآن الكريم، وكانت تراجع معه ما حفظ قبل الذهاب إلى شيخ الكُتّابِ.

${ }^{10}$ See example: Abdul Basith Junaidy, "Menimbang Maslahah Sebagai Dasar Penetapan Hukum (Kajian Terhadap Pemikiran Muhammad Abu Zahrah)," Al-Qānūn 18, no. 2 (2015): 325-57. Sami E. Baroudi, "Sheikh Muhammad Abu Zahra (1898-1974) on International Relations: The Discourse of a Contemporary Mainstream Islamist," Middle Eastern Studies 54, no. 3 (2018): 415-41, https://doi.org/10.1080/00263206.2018.1434147.

${ }^{11}$ Muhammad Badrun Syahir, "Al-Imām Muhammad Abū Zahrah Wa Ma’ālim Fikrihi Al-Tarbawī," Jurnal AtTa'dib 8, no. 1 (2013): 163-203, https://doi.org/http://dx.doi.org/10.21111/at-tadib.v8i1.520.

${ }^{12}$ Zahrah, Zahrah Al-Tafäsìr, 1/19.

${ }^{13}$ Muhammad Abū Zahrah, Al-Mu'jizah Al-Kubra: Al-Qur'an (Kairo: Dār al-Fikr al-'Arabi, 1998), 36-41.

${ }^{14}$ Zahrah, Zahrah Al-Tafäsīr, 1/4-11. 
بدأت حياة محمد أبي زهرة العلمية عندما بلغ سن التمييز كفيره من أبناء القرية، فيتلقى مبادئ العلوم الأساسية في الكتاتيب. فحفظ القرآن الكريم، وتعلم المبادئ القر ائة والكتابة، ثم التحق بالمدارس النظامية وبما أتم حفظ القرآن الكريم وتعلم مبادئ العلوم المدنية كالرياضية والجغرفية بالإضيافة إلى العلوم العربية. وبعد أن أكمل دراسته الأولية واستظهر القرآن الكريم، التحق بالجـامع الأحمدي بطانطا، عام 1913م. ثم انتقل محمد أبوزهرة إلى مدرسـة القضياء الشرعي في عام 1916م، وتخرج منها عام 1925 م. وقـد نال شهادة العالمية من درجة أستاذ بتقدير ممتاز 15 . وبعد أن تخرج من مدرسة القضشاء الشرعي عام 1925م، عمل سنة بالمحاماة، وكان ذلك تـدربباً له، فكـوّن لنفسـه منهاجـاً لفههم الشـريعة، ظهر أثره فيمـا بعـد في طريق تناوله قضـايا الإسـلام ممـا زاده تعمّقاً و إيماناً بها. وفي عام 1927م، حصل محمـد أبو زهرة على شهادة دبلوم دار العلوم، وفي هذه السـنة عيّن مدرساً للعلوم الشرعية واللغة العربية بدار العلوم والقضاء الشرعي. وفي أول يناير1933م انتقل الشيخ محمد أبوزهرة إلى الأزهر، حيث وجـد مكانه في كلية أصهول الدين مدرساً للخطابة والجـدل ثم تاريخ الديانات والملل والنحل، وفيها أخرج أول مؤلف له وهو كتاب " الخطابة " وكتاب " تاريخ الجدل "، ثم كتاب " تاريخ الديانات القديمة " ثم كتاب " محاضرات النصـر انية" الـذي ترجم إلى عـدة لغـات. وفي ســة 1963م تـولي الإمـام - رحمـه الله - التـدريس في كليـة المعـاملات والإدارة بجامعة الأزهر، وكذلك معهد الخدمة الاجتماعية وغيره من المعاهد.17 وفي 2 نوفمبر عام 1934م، نقل مدرساً للخطابة بكلية الحقوق جامعة القاهرة (فؤاد الأول) مع بقائه مدرساً بالانتداب في كلية أصهول الدين التي استمربها إلى يونية 1942. و في سبتمبرسنة 1935م، انتقل فضيلته من تدريس اللغة العربية إلى تدريس الشريعة الإسلامية بكلية الحقوق جامعة القاهرة متدرجا في مر اتها من مدرس إلى أستاذ مسـاعد إلى أستاذ كرسي إلى رئيس لقسم الشريعة واستمر رئيساً لقسم الشريعة بكلية الحقوق إلى أن أختير وكيلاً للكلية مدة خمس سنوات و انتهت ببلوغه سن التقاعد عام 1958م. واستمر في التدريس بكلية الحقوق بعد سن التقاعد كأستاذ غير متفرغ وفي غيرها حتى رحل - رحمه الله - إلى جوار الرفيق الأعلى. 18

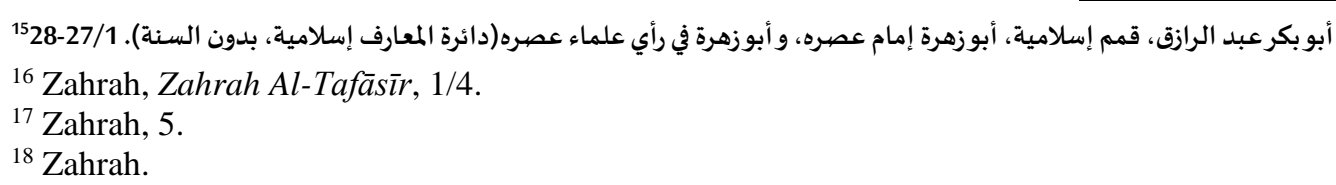


وقد احتل الشيخ محمد أبو زهرة - رحمه الله - مكانة عظيمة بين علماء عصره، يشهد بذلك معاصروه وتلاميذه 19 ، حيث أطلقوا عليه ألقابا علمية كثيرة، واعتبروه " إمام عصره "، "إمام وثيق في فقهه "، " دقيق في علمه "20. فقد كان أكثر علماء الأزهريلقبونه بذلك وهو يستحق هذا اللقب بجدارة. والو اقع أن فضيلته لم يكتسب مكانة علمية رفيعة من جاه ولا سلطان، إلا بسعة أفقه العلمي، وقدرته على العطاء والتاثير، وإظهار الحق في وجه الباطل، وجهاده الدؤوب في سبيل نشر تعاليم الإسلام السمحة الذي يعد مثلاً فاضلاً، يجب أن يقتدي به علماء هذا العصبر 21. وكان محمد أبو زهرة - رحمه الله - عالما متبحرا في الفقه وأصهوله، وعلوم القرآن وتفسيره، وخطيبا مفوها، وأصوليا متعمقا، ومجتهدا يقرع الحجة بالحجة والمنطق بالمنطق. وكان يرفض أن تكون كتاباته تردادا لأقوال الآخرين لما عرف عنه من اعتزازبنفسه وبغضها لسيطرة الآخرين بغير الحق 22 و كان مفزع أهل العلم في كل مشكلة تعِّن، وكان له من رسوخ القدم.23. وهذه النبوغ و العلوم المتعددة والثقافات الواسعة لم تأت من فراغ، فهويتحدث عن نفسه ويقول : " ولقد كانت حياتي و أنا في مرحلة الصبا جادة لا هزل فيها، ولم تصبني صبوة الشباب، فما دعت نفسي لحب أستغرقها، ولا لشهوة جامحة دفعتها، لا لكره في النساء، ولكن لجد في العمل "24. وكان فضيلته مجدا وشغوفا بالعلم والدرس والتأليف، ولم ينقطع عن المحاضرات والندوات في مصروغيرها 25. وليس أدل على ذلك من تلك المؤلفات التي ألفها، فإن معظمها عبارة عن محاضرات ألقاها على الطلاب في الندوات. و لقد عرف فضيلة الشيخ - رحمه الله - بجر أته في الحق وشجاعته، واشتهر بالعزة وكرامة النفس،

والصلابة والصيدع بكلمة الحق، والذكاء الحاد وقدرته على مقارعة الخصوم بالحجج البالغة والبراهين السـاطعة26 وكان قد ابتلي وصبر، حيث منع من الكتابة، والفتيا، وإلقاء المحاضرات، ونشر فكرته بين جماهره. وأمره السلطة أن لا ينتقل من جدار بيته لا يراه أحد ولا يرى هو أحداً. وقد صبر - رحمه الله- ولم يتملق أحد من السلطة أو أعوانها. بل

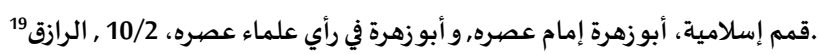

من أعلام الحركة والدعوة الإسلامية المعاصرة, المطبعة الأولى. (كويت: مكتبة المنار إسلامية, 2001)، 592.

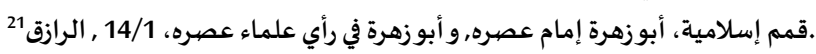

22 Zahrah, Zahrah Al-Tafāsīr, 1/6.

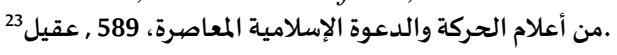

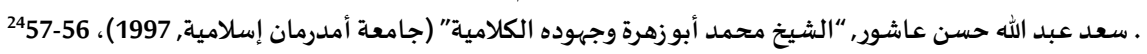

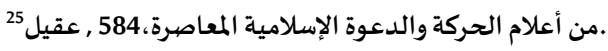

عقيل،
} 
أنه رفض أن يقوم أحد المقربين إليه بالشفاعة له عند السلطان، ذاكراً أن الشيخ ليس له طموحات سياسية أوغير ذلك من المآرب الدنيوية.27.

و بعد عمر حافل قضياه في التعلم والتعليم والتأليف وإظهار الحق والدعوة إلى الله العلي القدير بالحكمة والموعظة الحسنة. لقي الإمام أبو زهرة - رحمه الله - وجه ربه راضيا مطمئنا، في الساعة السابعة والنصف من مسـاء يوم الجمعة التاسع عشر من شهر ربيع الأول عام أربعة وتسعين وثلاثمائة وألف من الهجرة، المو افق الثاني عشر من إبريل سنة 1974م. وقد كان هذا بالقاهرة في منزله بالزيتون. و كانت وفاة عالمنا الجليل خسارة للأمة الإسلامية. وإن المكتبة الإسلامية مدينة للإمام - رحمه الله - بهذه المؤلفات الإسلامية التي خطها بقلمه، فهي ثروة عظيمة وتر اثا علميا كبيرا. حيث قاربت الثمانين كتابا، أكثرها من المراجع الكبيرة، فضلا عن المقالات التي كان ينشرها، والفتاوى التي يحررها8. وهي ثروة قيمة من المؤلفات والأبحاث والمقالات مما يدل على جهوده العلمية العظيمة التي بذلها في خدمة الإسلام والمسلمين. ومن بين مؤلفاته القيمة: المعجزة الكبري : القرآن، أصهول الحديث، تاريخ الجدل في الإسلام، تاريخ المذاهب الإسـلامية فى السياسـة والعقائـد و تـاريخ المـذاهب الفقهيـة، الـديانات القديمـة : مقارنـة الأديـان، مححاضـرات فى النصـر انية، أحكام التركات و المواريث، الأحسوال الشخصـية، أصهول الفقـه، بحـوث في الربـا، الجريمـة والعقوبـة في الفقـه الإسـلامي، شـرح قـانون الوصـية : دراسـة مقارنـة لمسـائله و مصيـادره الفقهيـة، العلاقـات الدوليـة فى الإسـلام ، فلسفة العقوبة فى الفقه الإسلامى، التكافل الإجتماعى فى الإسـلام، تنظيم الإسـلام للمجتمع، عقد الزواج و آثاره، و تفسير القرآن الكريم" زَهْرَة التفاسير" (وهو موضبوع بحثنا)، وغيرها. نبذة عن تفسيرزهرة التفاسير القـارئ لهـذا التفسـير سـيجده كاسـمه " زَهْرَة التفاسـير"، فالكتـاب يحتـوي على نخبـة مـن أقـوال وآراء المفسرين القدماء والمعاصرين، إضيافة إلى المعاني السامية التي أضافها المؤلف في هذا التفسير. فالمؤلف كما وصفه 
بعض العلمـاء:" بأنه أشـبه النـاس بالإمـام الغزالي في بلاغـة كلامه وإخـلاص حديثـه وغزارة عبار اتـه وقـوة حجــهـ 29. فهذه المكانة العلمية يلتمسها القارئ من خلال قراءة هذا التفسير. هذا، وقد اتسـم كتاب " زَهْرَة التفاسير" للإمام محمـد أبي زهرة بسـمات كثيرة يكتشـف من خلالهـا ملامحهـ العامـة، ويمكـن إجمالهـا في الأمـور التاليـة: اهتمامـه بالتفسـير بالمأثور والمعقــول، اهتمامـه بالمناسـبات بين السـور والآيات، تحدث عن غرض العام من كل السور، وهوشبيه بالتفسير المجمل. و اهتمامه بالجو انب البلاغية وإعجاز القـرآن والكشـف عـن معانيه ومراميـه. و إظهار مـا فيـه مـن سـنن الكـون ونظم الاجتمـاع ومـا اكتشـف من الحقـائق العلميـة. و المجمــل في عـرض القضـايا الفقهيـة وعـدم التعصـب بالمـــاهب الفقهيـة، والبعـد عـن الإسـر ائليات

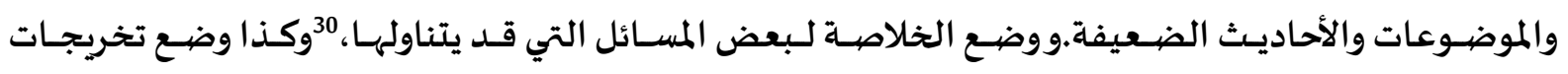
للأحاديث والمراجع وبعض التعليقات المهمة في الهامش. والجدير بالذكرهنا، أن تفسير" زَهْرَة التفاسير" لم يكن كاملا لثلاثين جزءً، وقد شـاء القدر أن يفسر - رحمهـ الله - من أول سورة الفاتحة حتى الآية 74 من سورة النمل. قامت بطبعه دار الفكر العربي، مدينة نصر القاهرة ، بلا تاريخ للطباعة. يقع هذا الكتاب في عشرة مجلدات. وتفصيلها كالآتي : المجلــد الأول : مـن أول ســورة الفاتحـة حتى الأيـة 185 مـن سـورة البقـرة.( ص:1- 560). وفيـه : ترجمــة مختصرة عن الإمام ( ص: 3- 11). مقدمة المؤلف (ص:13- 15 ). الافتتاحية ( ص: 17- 19). تمهيد ( ص: 21- 41 ). و المجلــ الثـاني : مـن الآيـة 186 مـن سـورة البقـرة حتى الآيـة 12 مـن سـورة آل عمـران.( ص: 561- 1120 ). و المجلــد الثالث : من الآية 13 من سورة آل عمران حتى الآية 39 من سورة النسـاء. ( ص: 1121- 1680 ). والمجلد الر ابع : من الآية 40 من سورة النساء حتى الآية 53 من سورة المائدة ـ ( ص: 1681- 2240 ). و المجلد الخـامس : من الآية 54 من سورة المائدة حتى الآية 25 من سورة الأعراف. ( ص: 2241- 2800 ).و المجلــ السـادس : مـن الآيـة 26 مـن سـورة الأعـراف حتى الآيـة 68 مـن سـورة التوبـة (ص: 2801- 3360 ). و المجلـــ السابع : من الآية 69 من سورة التوبة حتى الآية 17 من سورة الرعد (ص: 3361 - 3920 ). و المجلد الثامن : من الآية 18 من سـورة الرعـد حتى آخر سـورة الإسـراء (ص: 3921- 4480 ). المجلـد التاسع : من أول سـورة الكهـف حتى آخر 
سورة الحـج. ( ص: 4481 - 5040 ). والمجلد العاشر: من أول سـورة المؤمنون حتى الآية 74 من سورة النمل. ( ص: 5041- 5482 ). وإذا نظرنا في كل مجلد الذي يتروح ما يين 441 إلى 560 صفححة، فإن الغالب هو 559 صفحة. هـذا، وقـد وضـع الإمـام محمـد أبـوزهـرة - رحمـه الله - في المجلـد الأول مـن كتابه: المقدمـة، والافتتاحيـة، و تمهيد. تحدث المؤلف في مقدمة كتابه عن قصهة تعلقه بالقرآن وتفسيره، و إنه بدأ منذ أن كان طالباً للعلم. وقد كان من أمنياته العلمية أن يكون دائما قريباً من القرآن الكريم، يراجع الكتب التي تصبدت للتعريف بمعانيه، مؤمناً بأنّ علمه هو علم الإسلام، بل هو علم النفوس البشرية، وأسرار الوجود، و أنه علم النبوة الإلهية في مختلف العصور. وفي نهاية المقدمة بيّن فضيلته أنه قد كتب كتاباً ليكون مقدمة للتفسير ، وهو الكتاب الذي سماه " المعجزة الكبرى ". يقـول الإمـام - رحمـه الله - في هـذا الصيدد:" فهـذا الكتاب وإن كان مقصـوداً بـالجوهروالذات، هـ أيضياً مقدمة للتفسيرويغني عن كتابة مقدمة جديدة و إنا بعون الله تعالى نتجه إلى الله تعالى ضـارعين إليه أن يمدنا بعونه وتوفيقهـ في القيام بحق كتابه الكريم علينا، و إننا بكرمه وفضله دائبون على كتابة ما قصيدنا حتى يو افينا الأجل المحتوم ونحن في جواركتابه العزيز، عاملين لانبتعد عن عرفه ولا تتجافى مقاعدنا عنه" 31 ثم بين فضـيلته السـبب الـذي مـن أجلـه كتب هـذا التفسـير، وذلك يرجـع إلى أمرين :أولهـا: إن كثيرا مـن التفاسير مملوءة بأقوال في علم الكلام ومذاهبه، وآراء الفقهاء والاسـتلال كل صـاحب مذهب على مذهبه،وليس لها علاقـة بالتفسيروثانيها:عـدم مطابقة أقوال بعض المفسرين مع المبـادئ المقررة في القرآن كأقوال المفسـرين في

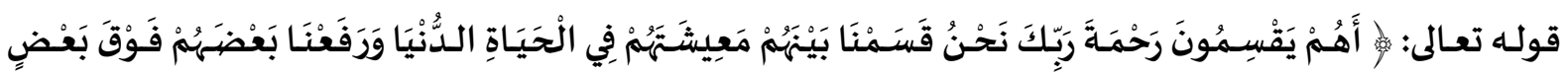

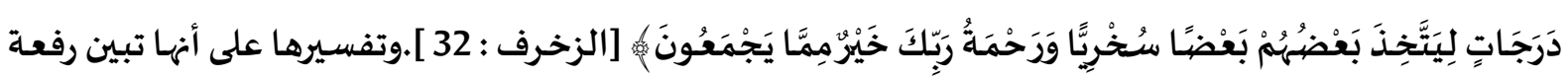
الأغنياء على الفقراء، وما ذلك بصحيح في المبادئ الإسلامية، ولا المقررات الدينية.32 وتكلم الإمام محمد أبوزهرة - رحمه الله - في تمهيد كتابه " زهرة التفاسير"، عن رحلته مع القرآن وتفسيره، و أنه بـدأ بتـدريس التفسيرفي التـاريخ 10 أكتوبر 1927م عندما عبيّن فضيلته مدرسـاً بتجهزيـة دار العلـوم والقضيـاء الشرعي. ثم عندما تنحى العارف بالله الشيخ الخضرحسين33 عن كتابة التفسير في مجلة " لواء الإسلام " وطلب أبا

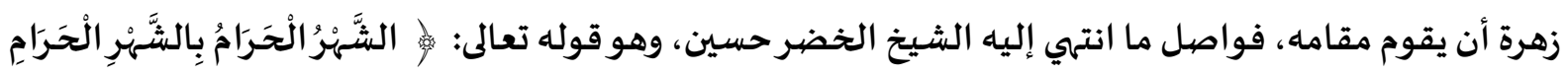

${ }^{31}$ Zahrah, 1/15.

${ }^{32}$ Zahrah, 17-19.

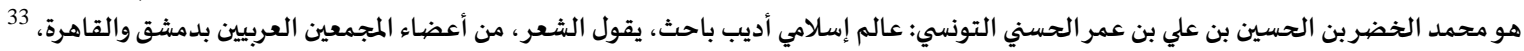

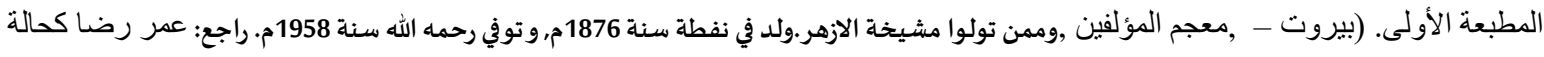
لبنان: الرسالة, 1993)، 279/9. 


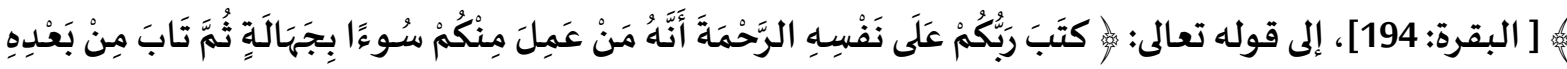

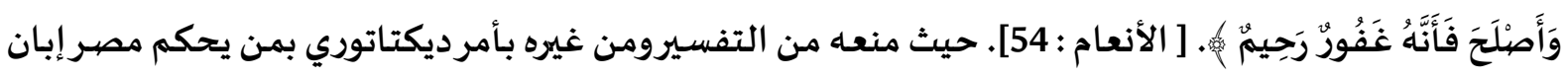
ذلك. ولما انكشفت الغمة،، وزال الحكم الديكتاتوري ، عاد مرة آخري فضيلته بكتابة التفسير. وفي هذا الشأن يقول الإمام محمد أبوزهرة : "ولما تكشفت الغمة وزال الحكم الطاغوتي، وزالت آثاره التي بقيت بعده شهوراً، وحملت القلم لأعود إلى أداء الواجب .... وقد ألح عليّ الكثيرون من أهل العلم وطلابه أن أتم ما بدأت في " لواء الإسلام" وتكرر الطلب، فوجدت أن من الواجب عليّ أن أقوم بكتابة التفسير مستعيناً بالله، متوكلاً عليه، ضيارعاً إليه أن يمن بتوفيقه، فلولا توفيقه ما اهتدينا إلى عمل، وما أتممنا عملاً بدأناه. فابتدأت بكتابة الجزء الـذي كتبـه الإمـام الخضـر، ليكون التفسـير كلـه نسـقاً واحسداً، وعلى منهـاج واحسد، وهـا نحـن أولاء نسـيرفي الطريق ضارعين إليه سبحانه وتعالى أن نصل إلى الحق فيما نكتب"34 وفي النهايـة، إنه من الصعوبة جـداً على أي باحث، أن يحسدد تحديدا زمنيـا دقيقـا وقت كتابة أيـة مؤلفـات ألفهـا عـالم مـن العلمـاء. حيـث لـم يصـرح الإمـام محمـد أبـوزهـرة - رحمـه الله - تحديـد الزمان الـذي بـدأ فيـه تأليفـه

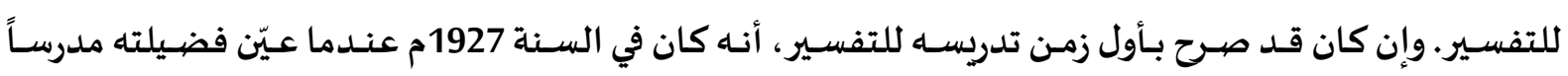
بتجهزية دار العلوم والقضشاء الشرعي. ولكن من المؤكد أن هذا التفسيرهو آخرما كتبه، وكان ذلك في السـنة 1974م الزمن الذي توفي فيه الإمام محمد أبوزهرة - رحمه الله -.

منهج الإمام محمد أبي زهرة في القراءات من خلال تفسيره

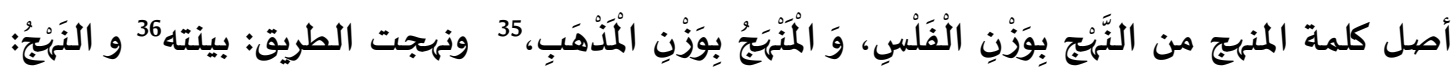

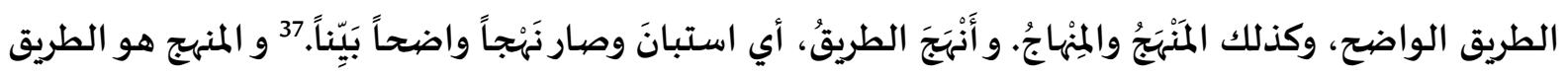
الواضح 383. وهو وسيلة محددة توصل إلى المعينة 39. وعلى هذا، فإن كلمة المنهج تعني الطريق الواضح الذي لا

\footnotetext{
${ }^{34}$ Zahrah, Zahrah Al-Tafāsīr, 1/22.

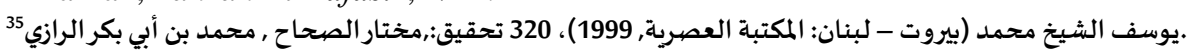

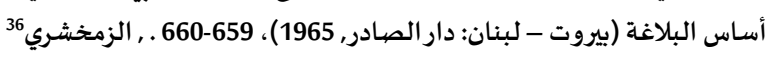

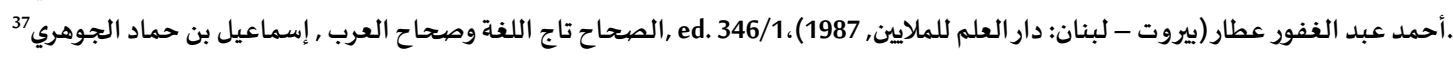

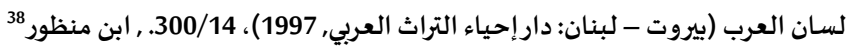

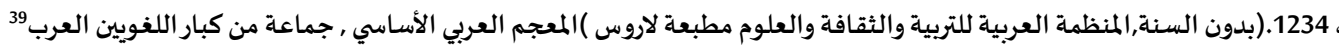


يلتبس على سـالكه سواء أكان حسيا أو معنويا، وإن كان غلب استعماله في المعني.40 و منهج محمد أبي زهرة تجاه القراءات يعني طريقه التي يسير عليها في معاملته مع القراءات في تفسيره.

القراءات جمع القراءة، وهي مصيدرقرأ. وفي اصطلاح الفن: مذهب يذهب إليه إمام من أئمة القراء مخالفا

به غيره في النطق بالقرآن الكريم مع اتفاق الرو ايات والطرق عنه سواء أكانت هذه المخالفة في نطق الحروف أم في نطق هيئاتها ، 41 أو"علم بكيفية أداء كلمات القرآن واختلافها بغزو الناقلة ".42

وقد اشتهر من الصحابة سبعة43: عثمان، وعلي، أبي بن كعب، وزيد بن ثابت، و أبو الدرداء، و ابن مسعود،

و أبو موسى الأشعري. وقد قرأ على كل واحد منهم جماعة من الصحابة ثم أخذ عنهم خلق من التابعين.4. ثم ظهرفي

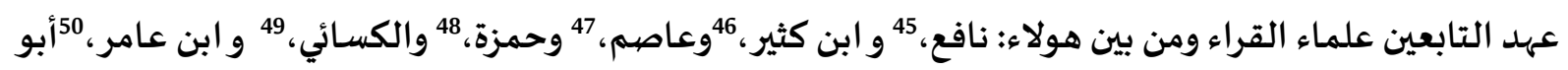
عمرو 51 إضافة إلى هؤلاء السبعة، قراءة يعقوب، 52 وقراءة خلف،53 وقراءة يزيد بن القعقاع - أبي جعفر -. 54 ثم قراءة الحسن البصري،55 وقراءة ابن محيصن، ‘وقراءة يحي بن اليزيدي، 57 وقراءة الأعمش.5 ${ }^{56}{ }^{56}$ فاكتمل عدد القراء إلى الأربع عشرة.

جماعة من كبار اللغويين العرب

${ }^{41}$ Muallaf Mointi and Kholid Mootalu, "Nasy`ah Al-Qirāah Wa Asbāb Ikhtilāfāt Al-Qurrā’ Fīhā,” ‘A Jamiy : Jurnal Bahasa Dan Sastra Arab 7, no. 1 (June 24, 2018): 95-118, https://doi.org/10.31314/ajamiy.7.1.95118.2018.

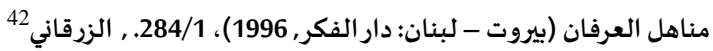

. تحقيق: سعيد المندوب (بيروت - لبنان: دار الفكر, 1996)، 197/1 الإتقان في علوم الفينان القرآن.

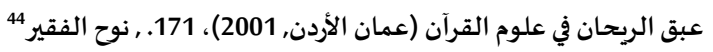

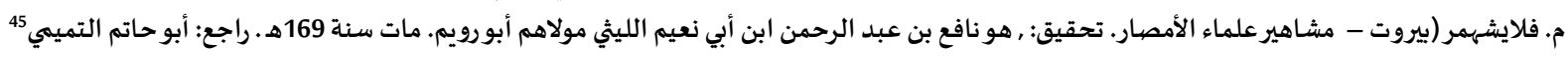

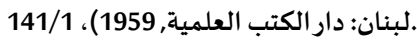

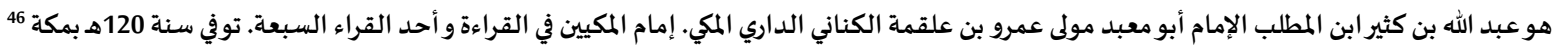

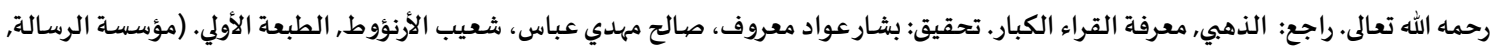

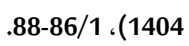

هو الإمام أبو بكر عاصهم بن ابي النجود الأسدي مولاهم الكوفي القارىء، أحد السبعة واسم أبيه بهدلة على الصحيح. توفي عاصهم في آخرسنة سبع وعشرين 1404، 47

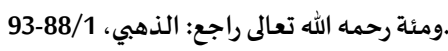

رحمه الله سنة 156هـ هوحمزة بن حبيب ابن عمارة بن إسماعيل الإمام أبوعمارة الكوفي مولى آل عكرمة بن ربعي التيمي الزيات أحد القراء السبعة مات حمزة الذهي،

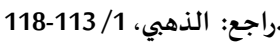

هو علي بن حمزة الكسائي الإمام أبو الحسن الأسدي مولاهم الكوفي المقريء النحوي أحد الأعلام. ولد في حدود سنة 120هـ توفي برنبويه سنة 89هـ. راجع : 49

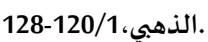

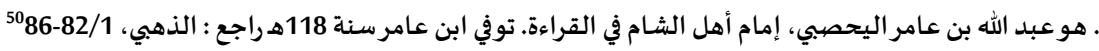

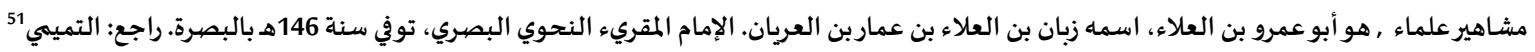
153/1، الأمصيار.

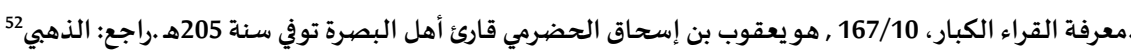

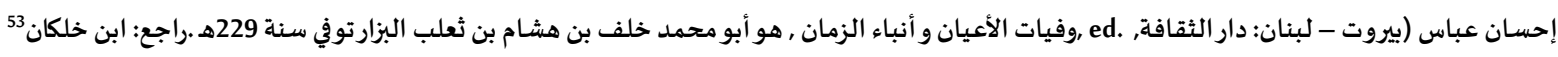
243-241/2، 1968.

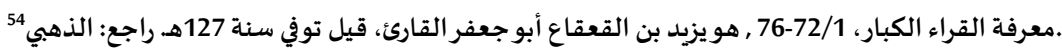

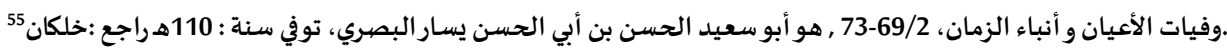


والقراءات الصحيحة المتو اترة هي كل قراءة و افقت أحد المصياحف العثمانية ولو احتمالاوو افقت اللغة العربية ولو بوجه وصيح سندها. و يجب على الأمة قبولها ولا يجوز ردها ولا يحل إنكارها. ومتى اختل ركن من هذه الأركان الثلاثة أطلق علهها ضعيفة أوشاذة أو باطلة، سواء أكانت عن السبعة أم عمن هو أكبر منهم. وهو ما اتفق عليه الأئمة المحققة"59 والقراءات المتو اترة التي تلقتها الأمة بالقبول إنما هي القراءات العشر التي أخذها الخلف عن السلف إلى يومنا هذا.60 - 20 - إن

وبعد قراءة وتتبع ما ورد في تفسيرزهرة التفاسير من القراءات، تظهر لنا ملاحه منهج الإمام محمد أبي زهرة

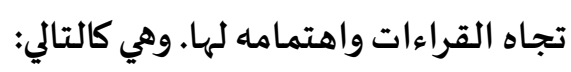
أولا: عرضها للقراءات في تفسيره

إن الناظر في تفسير" زهرة التفاسير" يلحظ أن الإمام محمد أبا زهرة - رحمه الله - قد اهتم بالقراءات

وضمن تفسيره كثيرًا من توجيهاتها. ذلك بسبب ارتباط القراءات الوثيق بموضع تفسيرواختلاف الأحكام، و كما ذكر العلماء؛ أن اختلاف القراءات يظهر اختلاف الأحكام الفهم

والغالب في تفسير الإمام محمد أبي زهرة - رحمه الله -، أنه لا ينسب القراءات إلى صاحهها، و إنما يكتفي بعبارته: " هناك قراءتان، والقراءة الأخرى، أو قراءة أهل مككة، هنا قراءتان "، وغير ذلك من العبارة 62 وهذا ربما كان لاختصار المقام و اكتفاء المقصهود لبيان الأحكام المتعلقة بتلك القراءات، لا لسردها بأسـانيدها.

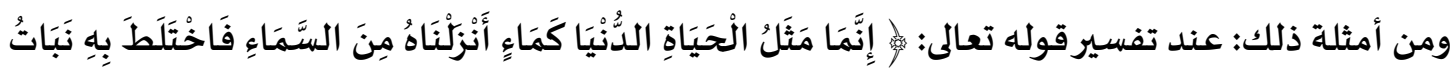

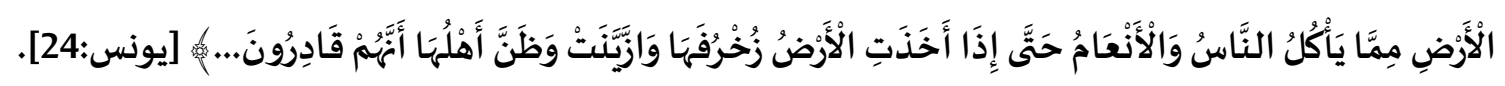

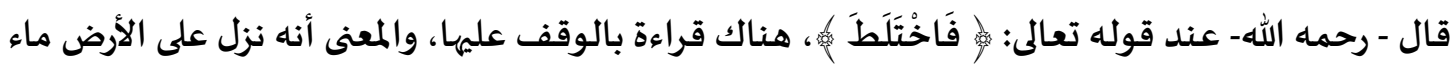

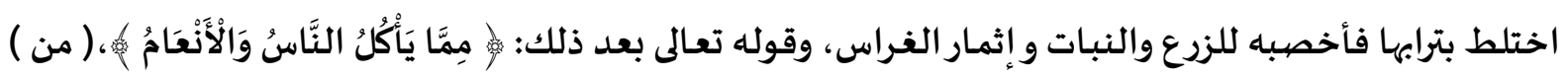
بيانية، لبيان نتيجة الاختلاط. والقراءة الأخرى بغيروقف عندهُ فَاخْتَلَطَ بُ، فيكون المعنى هو الاختلاط بنبات الأرض

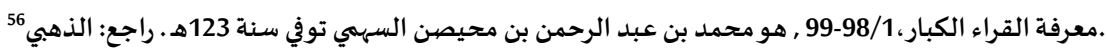

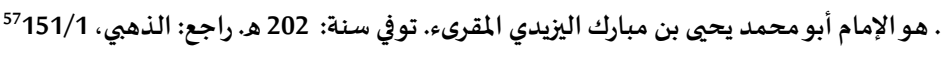

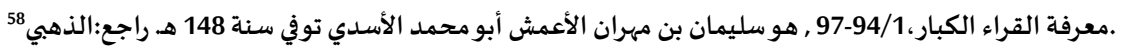

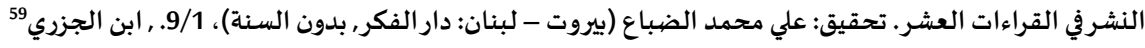

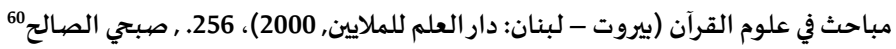

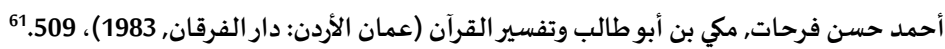

${ }^{62}$ Zahrah, Zahrah Al-Tafāsīr, see example:1/61, 2/681, 4/1665, 7/3429, 8/4210.
} 
دلالة على أن البذريلقى في الأرض ويرجى من الله إثمارها، ويكون اسم النبات قد استعمل فيما هو إضـافة باعتبار ما يكون وتلك علاقة من علاقات المجاز المرسل كأن العنب خمرا باعتبار ما يكون ... " 63

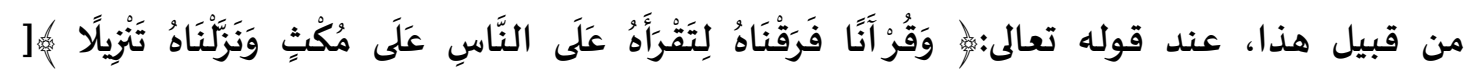

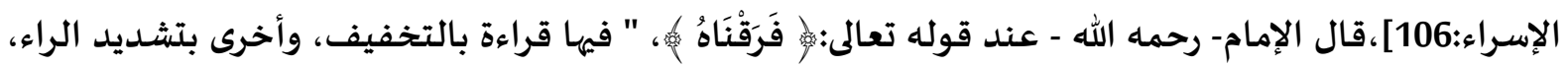
والمعنى واحد ومتلاق، وهو أنه نزل مفرقاً، ولم ينزل دفعة واحدة، بل نزل منجماً نجماً بعد نجم على حسب ما تقتضيه حكمته تعالى وإرادته وكان ينزل مع الحوادث وهي تشير إلى بيانه ..."64

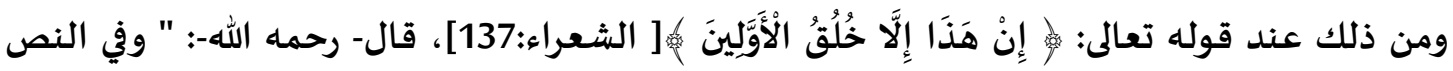
الكريم قراءتان: إحداهما بضم الخاء واللام، والمعنى على هذا يتضمن أولاً أن ما هم عليه من شرك، وقد اتبعوا فيه آباءهم، كما قال المشركون، وجدنا عليه آباءنا، ويتضمن ثانياً أنما هم عليه منبطش جعلهم جبارين هو خلق الأولين من قومهم، لوذا عبروا بخلق بدل دين ليشملها معاً. والقراءة الثانية: هي خلق بفتح لخاء وسكون اللام ويكون المعنى

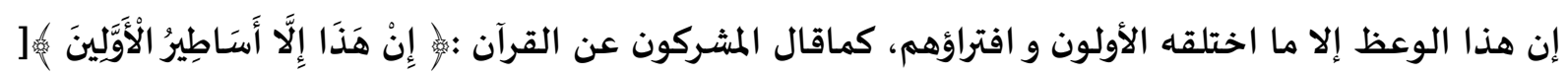
الأنعام: 25]". وبالنسبة الضئيلة، ينسب الإمام - رحمه الله - القراءة لصاحبها، ومثال ذلك: عند تفسير قوله تعالى: وبر

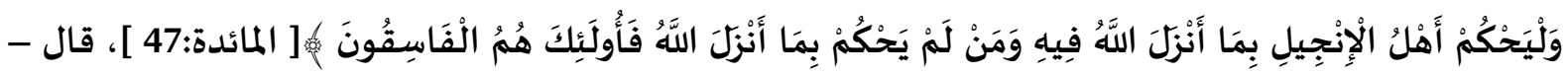
رحمـه الله - : " في هذا النص الكريم قراءات نذكر منها قر اتين في قوله تعالى : "وليحكم ": أولاهما قراءة حمزة66 بكسر اللام وفتح الميم، وتكون اللام للتعليل، يكون في مقام العطف على ما سبق، لأنه في معنى التعليل، ويكون المعنى على هذه القراءة ( و آتينا عيسى ابن مرسم الإنجيل فيه هدى ونور ومصدقا لما بين يديه من التوراة وهدى وموعظة للمتقين ). والقراءة الثانية: بسكون اللام، وسكون الميم على أن اللام للأمر، وسياق الكلام على هذا يوجب تقدير

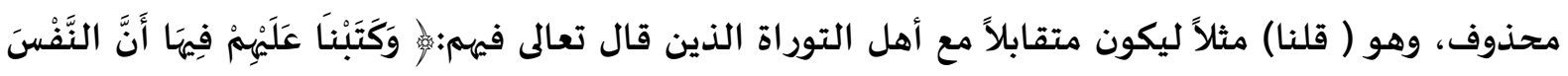

\footnotetext{
${ }^{63}$ Zahrah, 7/3549-3550.

${ }^{64}$ Zahrah, 8/4474.

${ }^{65}$ Zahrah, 10/5387.

رحمه الله سنة 156هـ ولد سنة ثمانين هجرية وأدرك الصحابة بالسن، مات حمزة هوحمزة بن حبيب ابن عمارة بن إسماعيل، أحد القراء السبعة.66

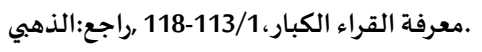


بِالنَّفْسِ.... [ المائدة:45 ]، فالمعنى: وقلنا ليحكم أهل الإنجيل، وعلى هذا التقدير يكون العمل بالإنجيل سابقاً على نزول القرآن".67

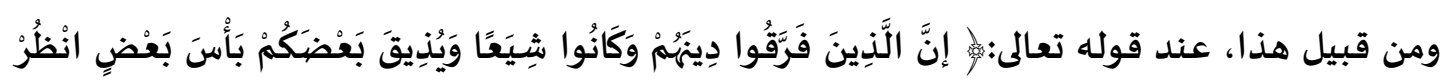

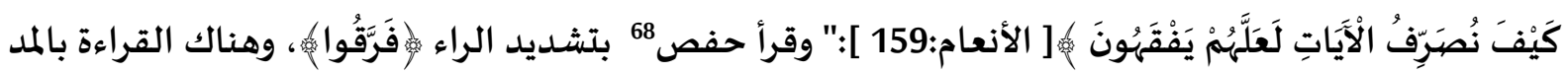
(فارقوا دينهم ) وتكتب في المصحف من غير ألف كشأن كثير من حروف المد في القرآن الكريم كالسموات، ولقد قال

على كرم الله وجهه : فرقوا حتى فـارقوا "69

ثانيا: حرصه على تو اتر القراءات

قال العلماء إن القرآن هو" كلام الله المعجز المنزل على الرسول محممد صلى الله عليه وسلم المتعبد بتلاوته، المكتوب في المصاحف، المنقول بالتو اتر المتعبد بتلاوته"70 ـولذا قرر العلماء على أن شرط القراءات المقبولة هو تو اتر الإسناد وليس فقط صححة الإسـناد وذلك لأن القرآن لا يثبت إلا بالتو اتر.71 والناظر لكتاب الإمام محمد أبي زهرة " زهرة التفاسير "، أنه يحرص كل الحرص على عرض وتعيين القراءات المتو اترة، وذكر إنها كلها من عند الله. 72 و لأن ليس جميع القراءات تنقل عن طريق التو اتر، وبالتالي فهي ليست من القرآن الذي يتعبد به والذي يصح به الصلاة .

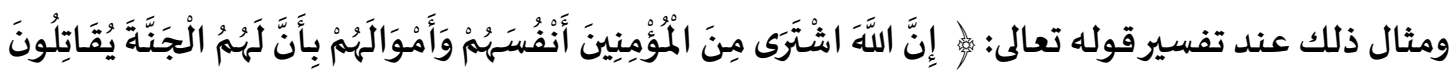

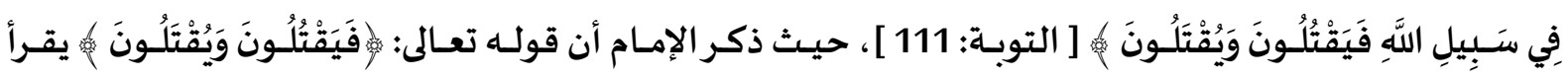
بقراءتين، " أولهما فيقتلون بالبناء للفاعل، والثانى بالبنـاء للمفعول، والقراءة الثانية بالعكس. وكل قراءة قرآن، وبمجموعة القراءتين تكون الآية داعية إلى ألا يفرقوا بين أن يَقتلوا أويُقتلوا، وإن الملكية التي أثبتوها لله تعالى تسـوغ ذلك، وتحيه كما نوهنا "

${ }^{67}$ Zahrah, Zahrah Al-Tafāsīr, 4/2220-2221.

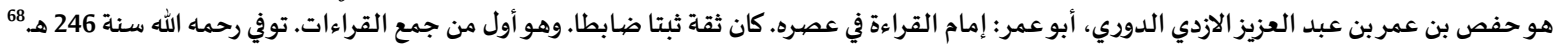

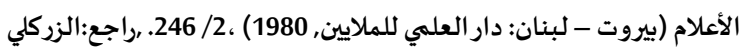

${ }^{69}$ Zahrah, Zahrah Al-Tafāsìr, 5/2754.

مناهل العرفان، 15/1, الزرقاني.

${ }^{71}$ Hasan, "AL- ȚAḤ̂̄Wİ'S METHOD TOWARDS THE VARIETY OF QIRAĀT IN TAFSIR AḤKĀM ALQUR'ĀN AND ITS IMPLICATION TO ISTINBĀṬ AL-AHKĀM.”

${ }^{72}$ Zahrah, $7 / 3559$.

${ }^{73}$ Zahrah, 3453. 


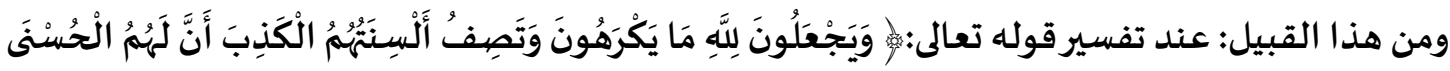

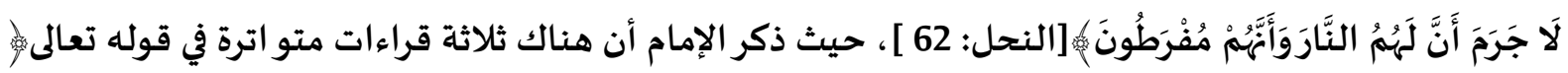
وَأَََّهُمْ مُفْرَطُونَ بُ،، قال - رحمه الله -: " وهذا على قراءة فتح الراء مع تخفيفها. وقرء بكسر الراء مع التخفيف، ويكون المعنى مفرطين في الظلم والمعاصي، وبذلك استحقوا النيران، قرئ بكسر الراء مع التشديد ويكون المعنى أهم مفرطون في طاعة الله تهالى أهملوها وتركوها فتركهم الله تعالى، وصاروا نسياً منسياً، والقراءات الثلث متو اترة، فيصيح أن تراد كلهاب.

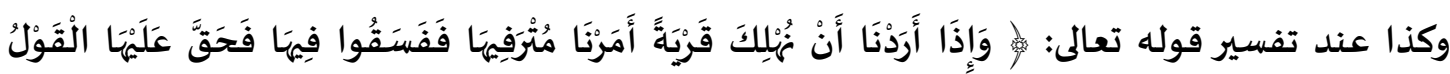

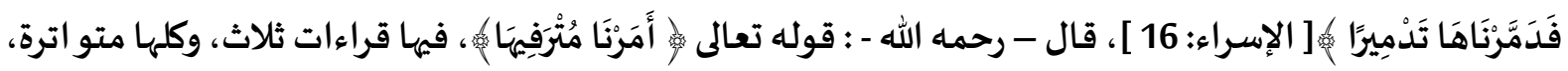
وكلها ذات معنى صادق مستقيم:

القراءة الأولى: ( أَمَنا)، بفتح ميم وهمزة من غير مد، والأمر هنا مجازي، ليس المقصهود به الطلب، و إنما

المقصود تسهيل أسباب الترف.وأسباب الاسترخاء الذي يلازمه، ولا يفرقان، ويتبعهما سيطرة الأهواء والشهوات. والقراءة الثانية: هي تشـديد الميم، أي ( أَمَّرنا) مترفيها بأن جعلناهم أمراءها، وحكامها فكانوا أمراء أشرار،

$$
\text { لأن الترف كما بيّنا يؤدي إلى الشروالأثرة. وحيث ما كانت الأثرة بعد الخير. }
$$

والقراءة الثالثة: أن الميم مفتوحة بالتخفيف ومد الهمزة أي ( آمرنا) ويكون المعنى كثرأي إذا أكثر الله تعالى

المترفين في الأمة عمها الفسـاد والفسق فدمرها الله سبحانه وتعالى تدميرا "75

و من حرصه على تو اتر القراءات: يجد القارئ الإمام - رحمه الله - يرد ردا ذريعاً على جهلة بعض

المستشرقين الذين يحسبون أن قواعد النحو حاكمة على قراءة متو اترة التي هي القرآن الكريم.

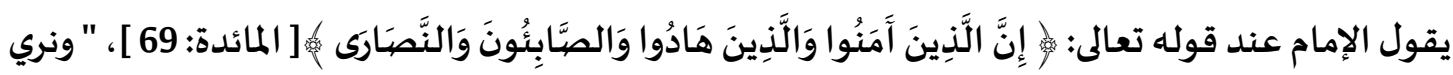

الصابؤون مرفوعة، وظاهر السياق أن تكون بالنصب فتكون والصابئين، وهذه قراءة ابن كثير، وقراءة الآخرين بالرفع، ولذلك تكلم المفسرون في هذه القراءة التي يقرأ بها الأكثرون. وقد خاضهوا في ذلك لأجل التخريج النحوى، وليس لأحد أن يخطئ القراءة من الناحية اللغوية، إلا أن يكون كجهلة بعض المستشرقين الذين يحسبون أن قواعد 
النحو حاكمة على القرآن، وذلك من فسـاد النظر، لأن القرآن فوق النحو، إذ النحو يستقى منه، وهو لا يخضيع لما يقرره النحوييون، بل هم الذين يخضعون له "76 ثالثا: الجمع بين القراءات يرى الإمام محمد أبوزهرة أن القراءات المتو اترة كلها لا تتباين ولا تتضارب، بل تتلاقى وتكمل واحدة معنى في الأخرى 77 ولا يمكن أن تتعارض قراءتان متو اتران؛ لأن القرآن لا يضرب بعضه بعضا. ولذا نراه يحمل القراءات الواردة في نص قر آني معين محملا واحدا، أو بعبارة أخرى أنه يوفق بين دلالات القراءات الواردة في نص القرآن الكريم، وأن هذه القراءات ليست متعارضة لإمكان الجمع بينها.

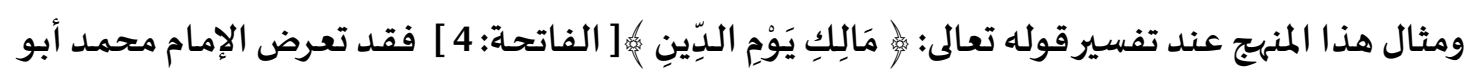

$$
\text { زهرة لذكر القراءات الواردة في هذه الآية. }
$$

فقـال - رحمـه الله - : " فيـه تختلـف في أشـكالها، ولا تختلـف في مضـمونها فقرئ هكذا: مالك يوم الـدين، وقرئ: مليك يوم الدين، وقرئ مَلِك يوم الدين، وقرأ أبو حنيفة رضي الله عنـه: ملَكََ يَومَ الدين، وقرئُ مالكاً يوم الدين، وقرئ: مالكُّ. والقراءات كلها تنتهى إلى معنى واحسد، وإن كانت تختلف في أعاريهها، والنص العثماني يشـملها جميعاً، ولا تخـالف في النسيخ المتو اتر، بيـد أن قراءة النصبب " مالكاً " تكون حـالاً مـن الذات العلية، أي أنه الرب للوجود كله والمنعم عليه بحلائل النعم، جليلها وخفهها، حال كونه مالكاً منبعد ذلك ليوم الجزاء، الذي يجزى كل نفس ما كسبت، إن خيراً فخير، وإن شراً فشر، ويوم الدين، تكون ظرفاً غير مضياف إليه، وكذلك في قراءة الرفع مع التنوين يكون يوم الدين ظرفاً للملك وكمال السلطان. وقراءة " مالك تفيد أن كل شيء مملوك لله تعالى في ذلك اليوم، ... و" مَلْك "و" مَلِك "، الفرق بينهما وبين قراءة " مالك " الفرق بين المصدرين، المِلْك ، والمُلْك، فالمِلْك استيلاء على الأشياء يكون مردها إليه، والمُلْك السلطان بالأمروالنهي ونتنفيذ ما يريد، وألا يكون معه آمرولا ناه، ولا حاكم سواه، ولا إرادة فوق إرادته، ولا حكم فوق حكمـه. ويلاحظ، أن معنى المُلْك يتضـمنه بالاقتضيـاء معنى المِلْك، لأن من ملك شـيئًا ملك السـلطان فيه، والسـيطرة عليهـ، فالمِلْك يقضي المُلْك والسلطان، المُلْك لا يقتضي المِلْك والسلطان؛ ولذلك يقال سبحان مالك الملك، ولا يقال مَلِك 
الملك. ور أينا كل قراءة متو اترة قرآن، وأن القرآن لا يخالف بعضها بعضـا، بل قـد يتم بعضهها بعضيا، وليس لنـا أن نراجح بين قراءة وقراءة، لأن كلتيهما تتمم الأخرى. وخلاصية القـول في القـراءتين أن قـراءة" ملك يوم الـدين " موضـحة لما تضـــتهـ " مالك يـوم الدين "، ولا نتصيور أن تتعارض قراءتان متو اتران؛ لأن القرآن لا يضرب بعضهه بعضياً " 78

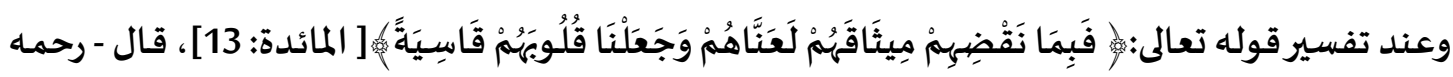

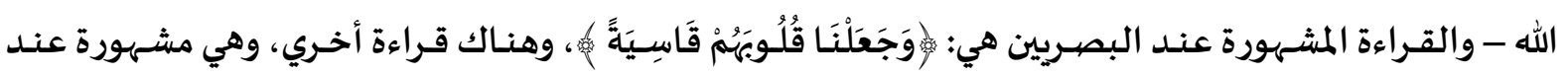

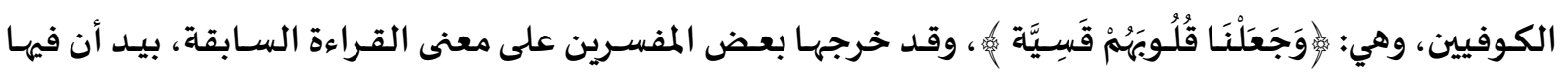
مبالغـة، ... والحق عندى أن كلتا القراءتين قرآن مادامت متو اترة والجمع بينهما ضـروري، والجمع بجعل إحـداهما تأتي بمعنى ليس في الأولى، يكون الأولى وتكون كلتاهما متممـة لأخرى، وبالجمع يكون المعنى: وجعلنا قلوبهم قاسية؛ لأن اختلط فهها الزيف، بأصـل الإيمـان، فعندهم إيمـان بـالله من غير إذعان لأحكلمـه، ولا تصـديقاً لرسـله، ولا قيـام بالتكليفات، والزيف أكثرمن الأصل، والنحاس لأكقر من الفضية، فصيلبت " 79

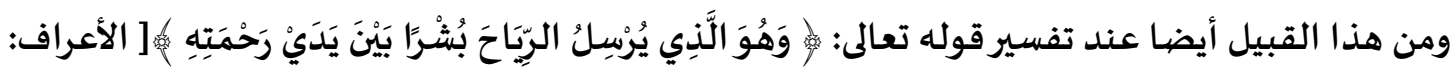

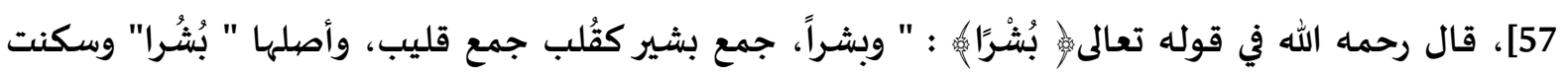
للتخفيف، وهناك قراءة بالنون، لا بالياء، وبضهم الشين، أي " نُشُرا " وهي جمع ناشر، كما أن شُهُدا جمع شـاهد، والمعنى أن الرياح تنتشر، مبشرة بأن السحاب سيمطر مطراً يكون غيثاً، وحول هاتين القراءتان قراءات أخرى، يبلغ عددها سبعاً، والفرق بينهما في الكلمة، ولا يؤثر في اختلافها في مضونها، وهي تكون منتشرة معلمة بالبشرى بالماء،

$$
\text { الذي يحي الأنفس، ويتي موات الأرض " } 80
$$

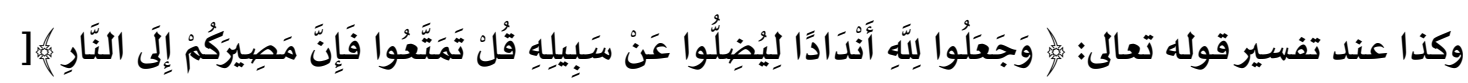

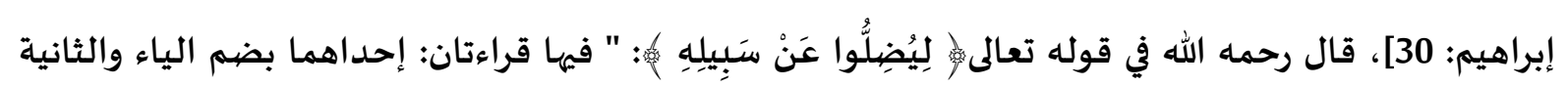
بفتحها، والأولى قراءة كثرة القراء، والثانية، قراءة من دونهم عددا وهما متو اتران، ونحن نعدهما كلتيهما قر آنا لا ريب فيه، ويكون المعنيان صحيحين ما دام غير متعارضين، ولا يمكن أن يكون ذلك في قراءتين متو اترين. فالمعنى

\footnotetext{
78 Zahrah, 1/60-61.

${ }^{79}$ Zahrah, 4/2078-2079.

${ }^{80}$ Zahrah, 6/2872.
} 
ليضلوا عن سبيل الله تعالى بذلك الجهل الذي جعلوا فيه الأحجار أنداداً لله تعالى، فإنه ذاته هلاك، وعاقبته ضلال، إذ العاقبة دائماً من جنس مؤثراتها والنتيجة دائماً من جنس مقدماتها "81 .

$$
\text { رابعا: بيان القراءات وتوجيهها }
$$

والمراد من توجيه القراءات هو بيان عللها و معناها وعربيَّتها. 82 ومما يلحظ من مسلكه، أن المفسر - رحمه

الله - يذكر القراءات ويتعرض لها بالتوجيه، وذلك ليبين بها ما جاء في القرآن الكريم، أو بعض جو انبه، والأمثلة على

$$
\text { ذلك عديدة، } 83 \text { وسأقتصبر على الآتي منها: }
$$

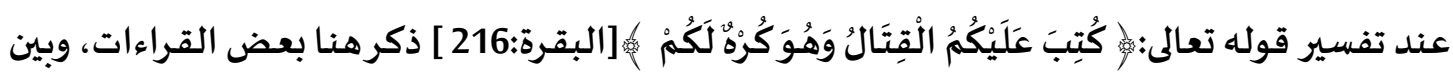

بها بعض ما جاء في الآية. فقال - رحمه الله - : " وقد قرئ بضم الكاف وفتحها، والضم أكثر، وهو بمعنى الكراهة؛ أي القتال لشدة ويلاته وما فيه من إزهاق الأرواح كأنه الكراهة نفسها، ويصح أن يكون كره بمعنى المكروه أي خبز بمعنى المخبوز، أي هو أمر مكروه في ذاته.

وعلى قراءة الفتح يكون فيه معنى الإكراه، فيكون المعنى عليه: كُتبَِّ عليكم القتال، وهو أمر أنتم تلجؤون

عليه إلجـاء، وتضـطرون إليه إضـطرارا؛ إذ إن الكره ضيد الطوع، فكأنكم لا تـدخلون الحـرب طائعين، بـل تـدخلونها مكروهين كارهين، مضطرين غير مختارين ...

والأمر على قراءة الفتح واضح؛ لأن القتال في الأمرغير مرغوب فيه لذاته، إنا اضطر المسلمون اضطراراً. كما

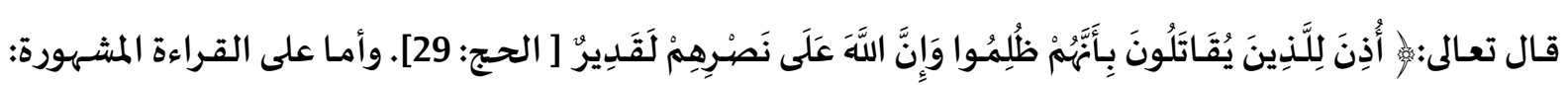
وهي قراءة ضم الكاف، فكيف كان القتال مكروها، مع أن الصحابة كان الموت في سبيل الله أحب إليهم، وكانوا يرون الشهادة في سبيل الحق غنما وليست غرماً ؟ "84

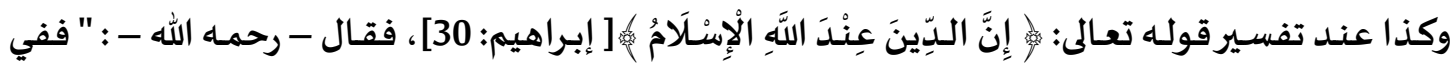

هذا النص الكريم قراءتان: قراءة بفتح همزة " أن "، وقراءة بكسرهمزة " إن"، وعلى قراءة الأولى يكون سياق النص

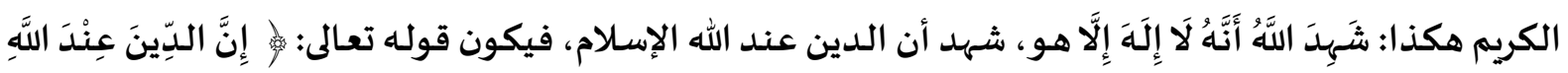

${ }^{81}$ Zahrah.

${ }^{82}$ Hasan Salem Habshan, "Quranic Recilation Instructions and Their Relevance to Arabic and Legal Sciences," Jāmiah Al-Syariqah Li Al-'Ulūm Al-Syariyyah Wa Al-Qanuniyyah 13, no. 1 (2016): 181-213.

${ }^{83}$ Zahrah, Zahrah Al-Tafāsīr, see example: 1/61, 650, 847, 3/1147, 5/2078, 6/3174, 7/3550, 8/4210, 9/4640, $10 / 5387$.

${ }^{84}$ Zahrah, 2/680-681. 


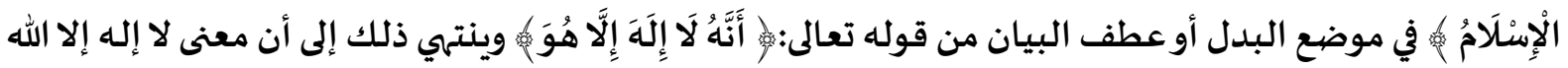

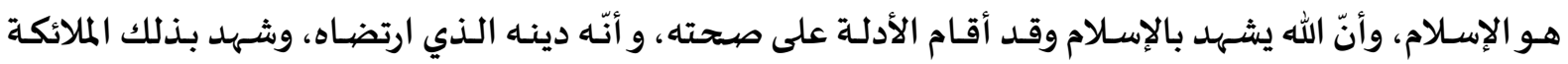
الأطهار بمـا أخبرهم بـه رب العـالمين، وشهـد بـه أولو العلم بمـا اسـتنبطوه، وهو دين العقل ودين الإخلاص، ودين الله تعالى.هذا على قراءة الفتح. أما على قراءة الكسـر، إن الكلام يكون مسـتأنفاً مقرراً لمعانى الآية السـابقة، وما اشتملت عليه من معانى الألوهية والعبودية والربوبية وعزة الله وحكمته؛ لأن دين الإسلام يقتضي الإيمان بكل هذا، فكأن سـائلا سـأل: ما هو الدين الذي يقرر هذه الحقائق؟ فقال سبانه وتعالى: إن الدين عند الله الإسلام "85

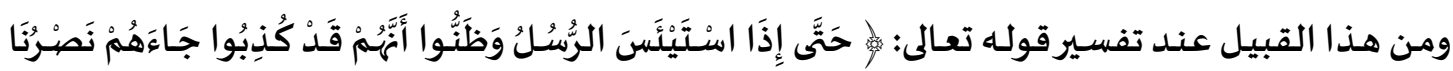

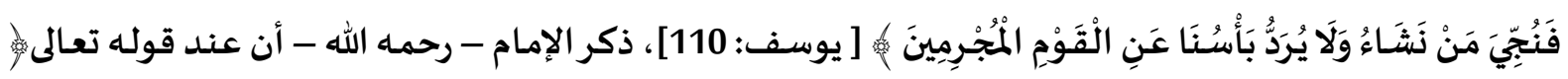

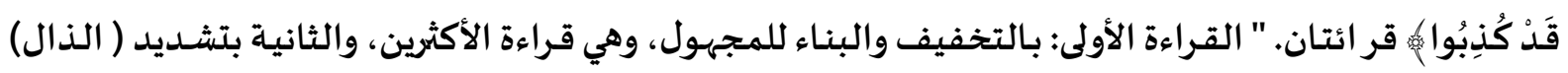
للبناء للمجههول أيضا، وهي قراءة أم المؤمنين عائشة رضي الله عنها وأرضاه، وطاشفة من القراء بعدها. والمعنى على قراءة التحفيف: علموا أههم تلقوا من جهـة الذين أرسلوا إلههم بالكذب، أي ظنوا أن الذين تلقوا عنهم أخبار الإنذاريظنون الكذب فيهم. وعلى قراءة التشـديد: يكون المعنى أن الرسل قـد استيئسـوا حتى ظنوا

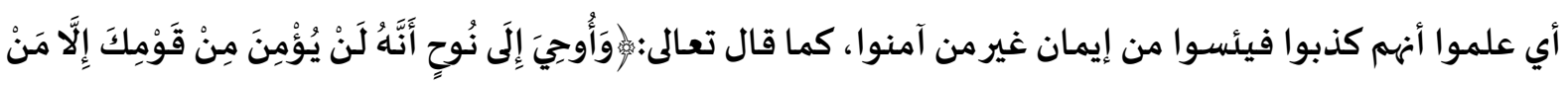
قَدْ أَمَنَ فَلَاتَبْتَبِسنْ بِمَا كَانُوا يَفْعَلُونَ 86 خامسا: توجياء القراءات الشاذة تعتبر القراءة شاذة، إذا لم يتو افر فيها شرط التو اتر. وهي كل قراءة لم تو افق أحد المصاحف العثمانية ولو بوجه، ولم تو افق اللغة العربية ولو بوجه و لم تصح سندها. وليس الشاذ قر آنا، لأن القرآن اسم للمتو اتر لفظه، وهو ما بين دفتي المصحف.87 وتعمل القراءة الشـاذة بمنزلة خبر الآحاد، كقراءة عبد الله بن مسعود في كفارة اليمين لِفَفَنْ لَمْ يَجِدْ فَهِيَّامُ ثَلَاثَةِة أَيَّامِ متتابعات مُهورة المائدة من الآية :89، فلفظ "متتابعات" من الشواذ، لأنه لم ينقلها أحد من الصحابة

${ }^{87}$ M. Ridha DS, “Kriteria Dan Ketentuan Qira'at Al-Qur'an,” Al-Qisthu: Jurnal Kajian Ilmu-Ilmu Hukum 13, no. 2 (March 30, 2015): 185-96, https://doi.org/10.32694/010400. 
غيره. وقد ذكر العلماء أن توجيه القراءة الشاذة أقوى في الصيناعة من توجيه المشههور، لأن في توجيه الشـاذ عونا على

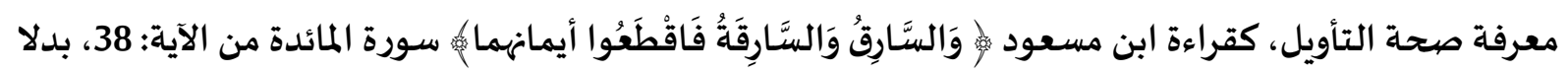

$$
\text { من " أيديهما " فيفهم من هذه القراءة ما يقطع في حد السرقة88. }
$$

ذكر الزركثي في البرهان، أن هذه الحروف و أمثلها أصبحت مفسرة للقرآن ولاسيما إذا رويت عن كبار

الصحابة، فأدنى ما يستنبط من هذه الحروف معرفة صدحة التأويل "89 ومن هنا شـاع بين ألسن العلماء: " اختلاف القراءات يظهر اختلاف الأحكام، ولهذا بنى الفقهاء نقض وضهوء الملموس وعدمه على اختلاف القراءة في لمستم و

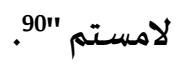

ومما يلحظ في تفسير الإمام محمد أبوزهرة ، أنه يقوم بتوجيه القراءات الشـاذة ويستخدمها لمعرفة تفسير

الآية واستنباط الأحكام الفقهية.

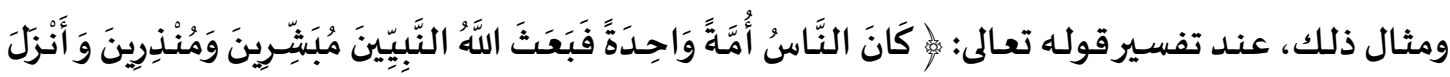

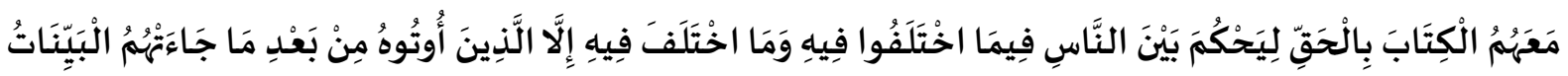

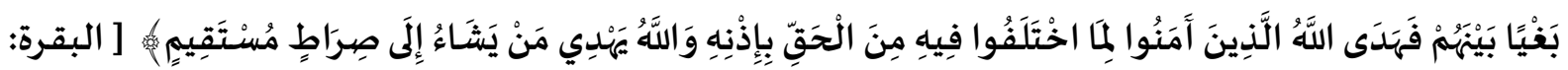

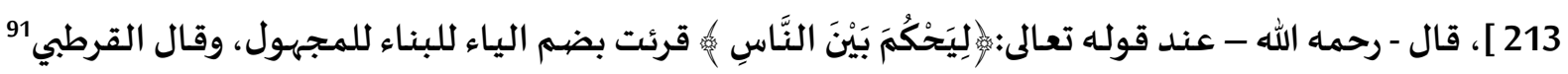
إهها قراءة شاذة؛ والمعنى عليها: أن الكتاب مشتمل على ما يحكم به بين الناس فيما يختلفون فيه مما يتعلق بالدنيا والآخرة، فهو المرجع الذي يـدركون بـ الحقق في ذاته إذا اختلفوا في العقائد أو الشـر ائع، أويوم الآخر، وهـو الحكم العدل إذا اختلفوا في شؤن دنياهم ومآرب الحياة "92.

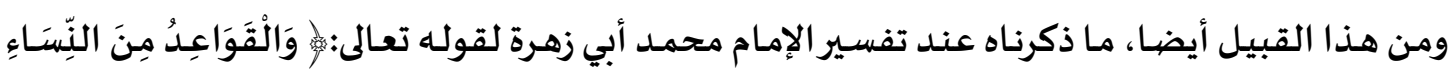

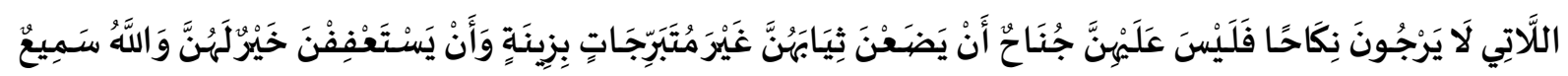

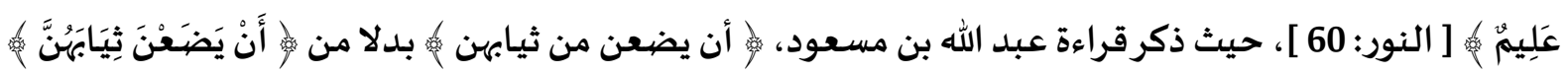

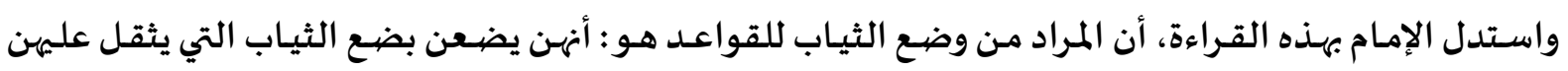

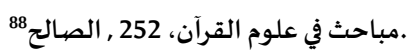

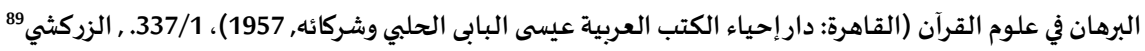

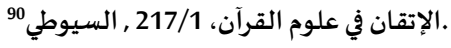

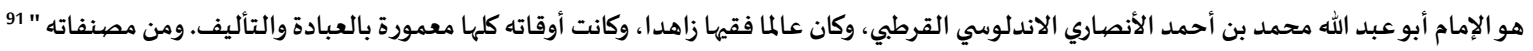

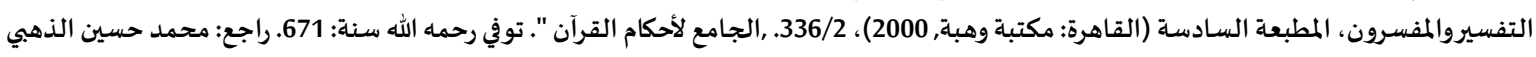

92 Zahrah, Zahrah Al-Tafāsīr, 2/666.
} 
حملها. قال - رحمـه الله - في هذا الصـدد: " أي بعض ثيابهن، والبعضية وإن لم تكن ( من ) في القراءات الأخريات ملاحظة فهها، وهي مفهومة من السياق "93 .

وهكذا نرى في هذا المبحث اهتمام الإمام محمد أبي زهرة - رحمه الله -بالقراءات وتوجيهاتها، وهو لا يذكر

القراءات المختلفة في تفسيره " زهرة التفاسير" إلا إذا ترتب على اختلافها اختلاف في المعانى، فذكرها كلها، على أهها كلها قرآن، و أن هذه المعانى كلها مقصيود في القرآن السـامى ودليل على إعجازه 94 و يكفينا ذلك على إثبات قدرته العلمية وثقافته الواسعة في مجال القراءة والقراء ـوالله أعلم بالصواب.

الخاتمة:

وفي نهاية المطاف يمكننا القول، بأن الإمام محمد أبي زهرة من خلال كتابه "أحكام القرآن الكريم" قد

أبدى اهتماما بالغا بالقراءات. و كان للإمام مناهج خاصة في معالجة القراءات والاستفادة منها في التفسير. وهي كالأتي (1) عند عرضه للقراءات أنه في الغالب لا ينسب القراءات إلى صاحهها إلا بالنسبة الضئيلة، و ربما كان ذلك لاختصار المقام. (2) الحرص على عرض وتعيين القراءات المتو اترة، و إهها كلها من عند الله (3) الجمع بين القراءات (4)بيان القراءات وتوجيهها (5) وتوجيه القراءات الشـاذة. وكان من بين أهدافه لمعالجة مسائل القراءات بالقراءات في تفسيره أولا: تأكيده أن القراءات المتو اترة كلها من القرآن، و أن المعانى تلك القراءات كلها مقصيود في القرآن السامى ودليل على إعجازه. وهو يرى أنه لا تعارض بين معان القراءات المتو اترة. ثانيا: استخدام القراءات لاستنباط الأحكام الفقهية ولتقرير المعاني عند تفسير الأية وذلك لارتباط القراءات الوثيق بموضع تفسيرواختلاف الأحكام.

المصيادروالمراجع

Al-'Ak, Khālid 'Abd al-Rahmān. Ușūlu Al-Tafsīr Wa Qawā'Iduh. Bairut: Dār al-Nafāis, 1986.

94 Zahrah, 1/19. 
Badrun, Muhammad. "Mengenal Muhammad Abu Zahrah Sebagai Mufassir." At-Ta'dib: Journal of Pesantren Education 6, no. 1 (2011): 79-94. https://doi.org/http://dx.doi.org/10.21111/at-tadib.v6i1.548.

Baroudi, Sami E. "Sheikh Muhammad Abu Zahra (1898-1974) on International Relations: The Discourse of a Contemporary Mainstream Islamist." Middle Eastern Studies 54, no. 3 (2018): 415-41. https://doi.org/10.1080/00263206.2018.1434147.

Effendi, M. R. ., Khoerunnisa, I., \& Syaprudin, D. (2021). Improving the Ability to Read the Qur'an Through Qiro'ati Method. Muttaqien Publishing, 1(1), 319-330.

Habshan, Hasan Salem. "Quranic Recilation Instructions and Their Relevance to Arabic and Legal Sciences.” Jāmiah Al-Syariqah Li Al-'Ulūm Al-Syariyyah Wa Al-Qanuniyyah 13, no. 1 (2016): 181-213.

Hadiyanto, A., \& Khumairoh, U. (2018). Makna Simbolik Ayat-Ayat tentang Kiamat dan Kebangkitan dalam Al-Qur'an. Hayula: Indonesian Journal of Multidisciplinary Islamic Studies, 2(2), 187-212.

Halimah B. "PERBEDAAN QIRA'AT DAN PENGARUHNYA DALAM ISTINBATH HUKUM.” Al-Risalah 19, no. 1 Mei (2019): 97-98.

Hasan, Moh. Abdul Kholiq. "AL- ȚAHĀWI'S METHOD TOWARDS THE VARIETY OF QIRAĀT IN TAFSIR AḤKĀM AL-QUR'ĀN AND ITS IMPLICATION TO ISTINBĀṬ AL-AḤKĀM.” Jurnal Studi Ilmu-Ilmu Al-Qur'an Dan Hadis 22, no. 1 (January 30, 2021): 93. https://doi.org/10.14421/qh.2021.2201-05.

—. "The Tafsīr Bi Al-Ma'sūr and Bi Al-Ra'yī in The Commentary of Abū Ja'far AlṬạ̣āwī (Study in Aḥkām Al-Qur'ān Al-Karīm.” Jurnal Studi Al-Qur'an 17, no. 2 (2021): 179-206.

Irham, Muhammad. "IMPLIKASI PERBEDAAN QIRAAT TERHADAP PENAFSIRAN ALQURAN.” Al-Bayan: Jurnal Studi Ilmu Al- Qur'an Dan Tafsir 5, no. 1 (July 13, 2020): 55-61. https://doi.org/10.15575/al-bayan.v5i1.8563.

Junaidy, Abdul Basith. "Menimbang Maslahah Sebagai Dasar Penetapan Hukum (Kajian Terhadap Pemikiran Muhammad Abu Zahrah).” Al-Qānūn 18, no. 2 (2015): 325-57.

Misbah, Muhammad. "PEMBACAAN AL-QUR' AN DALAM PERSPEKTIF IMĀM ALQURṬUI.” Hermeunetik 8, no. 1 (2014): $89-112$. https://doi.org/10.21043/hermeneutik.v8i1.907.

Mointi, Muallaf, and Kholid Mootalu. "Nasy’ah Al-Qirāah Wa Asbāb Ikhtilāfăt Al-Qurrā’ Fīhā.” 'A Jamiy: Jurnal Bahasa Dan Sastra Arab 7, no. 1 (June 24, 2018): 95-118. https://doi.org/10.31314/ajamiy.7.1.95-118.2018.

Muhammad Abū Zahrah. Al-Mu’jizah Al-Kubra: Al-Qur`an. Kairo: Dār al-Fikr al-’Arabi, 1998.

Narulita, S., Aulia, R. N., Nugrahaeni, E., Wajdi, F., Mardhiah, I., \& Hadiyanto, A. (2019, August). Religion Learning Strategies for the Z Generation BT - 1st International 
Conference on Education Social Sciences and Humanities (ICESSHum 2019). Retrieved from https://www.atlantis-press.com/article/125914745

Ridha DS, M. “Kriteria Dan Ketentuan Qira'at Al-Qur'an.” Al-Qisthu: Jurnal Kajian Ilmu-

Ilmu Hukum 13, no. 2 (March 30, 2015): 185-96. https://doi.org/10.32694/010400.

Siregar, K. I. (2015). "نظرة فى جمالية تعبير الحديث النبوي فى وصف حلاوة الايمان \&quot; دراسة وضعية. Jurnal Studi Al-Qur'an , 11(2), 182 - 202

Syahir, Muhammad Badrun. “Al-Imām Muhammad Abū Zahrah Wa Ma'ālim Fikrihi AlTarbawī." Jurnal At-Ta'dib 8, no. 1 (2013): 163-203. https://doi.org/http://dx.doi.org/10.21111/at-tadib.v8i1.520.

Syahrullah, Syahrullah. "Nuansa Fiqhiyah Dalam Zahrah Al-Tafasir Karya Muhammad Abu Zahrah.” Al-Bayan: Jurnal Studi Ilmu Al- Qur'an Dan Tafsir 1, no. 2 (2016): 131-38. https://doi.org/10.15575/al-bayan.v1i2.1597.

Zahra, M., Hadiyanto, A., \& Siregar, K. I. (2020). Karakteristik Pendidik Rahmani dalam Surah ar-Rahman. Jurnal Studi Al-Qur'an, 16(1), 89-100.

Zahrah, Muhammad Abū. Zahrah Al-Tafāsīr. Kairo, Mesir: Dār al-Fikr al-'Arab̄̄, n.d.

التميمي, أبو حاتم. مشاهيرعلماء الأمصار Edited by. .م. فلايشهمر. بيروت - لبنان: دار الكتب العلمية, 1959. الجزري, ابن. النشرفي القراءات العشر Edited by علي محمد الضبباع. بيروت - لبنان: دار الفكر.n.d,

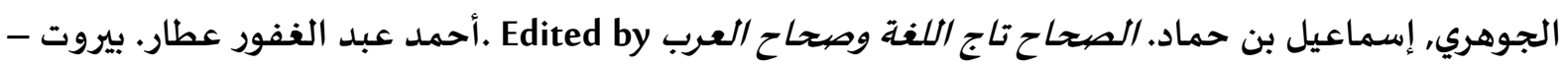
لبنان: دار العلم للملايين, 1987.

الذهبي. معرفة القراء الكبار Edited by ed. بشار عواد معروف، صالح مهدي عباس، شعيب الأرنؤوط. 1 st مؤسسة الرسالة, 1404. الذهبي, محمد حسين. التفسيروا المفسرون. 6 .th ed القاهرة: مكتبة وهبة, 2000. الرازق, أبو بكر عبد.قممى إسلامية، أبوزهرة إمام عصبره,وأبوزهرة في رأي علماء عصبره. دائرة المعارف إسلامية.n.d, الرازي, محمد بن أبي بكر. مختار الصحاح Edited by يوسف الشيخ محمد. بيروت - لبنان: المكتبة العصرية,

$$
\text { الزرقاني. مناهل العرفان. بيروت - لبنان: دار الفكر, } 1996 .
$$

الزركشي. البرهان في علوم القرآن. القاهرة: دار إحياء الكتب العربية عيسى البابى الحلبي وشركائه, 1957. الزركلي. الأعلام. بيروت - لبنان: دار العلهي للملايين, 1980. الزمخشري. أساس البلاغة. بيروت - لبنان: دار الصادر, 1965. السيوطي. الإتقان في علوم القرآن Edited by سعيد المندوب. ييروت - لبنان: دار الفكر, 1996. الصالح, صبحي. مباحث في علوم القرآن. بيروت - لبنان: دار العلم للملايين, 2000. 


$$
\text { الفقير, نوح. عبق الريحان في علوم القرآن. عمان الأردن, } 2001 .
$$

جماعة من كبار اللغويين العرب. المعتجم العربي الأساسي. المنظمة العربية للتربية والثقافة والعلوم مطبعة لاروس , n.d.

خلكان, ابن. وفيات الأعيان وأنباء الزهان Edited by .إحسان عباس. بيروت - لبنان: دار الثقافة, 1968. زرور, عدنان."رجل فقدناه الأستاذ العلامة الشيخ أبوزهرة." مجلة حضبارة الإسلام 3.(1974) عاشور, سعد عبد الله حسن. “الشيخ محمد أبوزهرة وجهوده الكلامية." جامعة أمدرمان إسلامية, 1997. عقيل, مستشار عبد الله. من أعلام الحركة والدعوة الإسلامية المعاصبرة. 1 st ed. .2001 فرحات, أحمد حسن. مكي بن أبوطالب وتضسير القرآن. عمان الأردن: دار الفرقان, 1983. كحالة, عمر رضيا. معجم المؤلفين. 1.st ed. ييروت - لبنان: الرسالة, 1993. منظور، ابن. لسان العرب. بيروت - لبنان: دار إحياء التراث العربي, 1997. 